\title{
Beyond propaganda: science coverage in Soviet Estonian media
}

\section{Arko Olesk}

\begin{abstract}
Previous studies have concluded that science coverage in Soviet countries was determined by the ideological function of the media. This paper analyses the science coverage in Soviet Estonian publications Rahva Hääl and Horisont in 1960/1967 and 1980 and demonstrates that the popularization of science existed as an independent function of articles. This suggests that the parallel developments in science communication on both sides of the Iron Curtain deserve further study.
\end{abstract}

Keywords

History of public communication of science; Representations of science and technology; Science and media

The Cold War period stands out in the history of science for the strong government and military patronage that led to new institutional arrangements and played a major role in the shape and structure of science [Oreskes, 2014]. In some cases, such as the space race, these factors also directly influenced the development of science communication and science coverage in the media, leading to the hype of science [Gregory and Miller, 2000, p. 48; Broks, 2006, p. 102]. While there were some periods of more critical coverage (especially the 1970s), the general science coverage during the Cold War was enthusiastic, optimistic and focused on popularizing, i.e. 'selling' science to the broader public to strengthen the social support and legitimation [Bucchi and Trench, 2014, p. 3; Nelkin, 1995]. At least this is the narrative about the history of science communication in the Western world. At the same time we know little about the parallel developments behind the Iron Curtain.

Why should the study of the Soviet-era science communication be relevant today? After all, it might be fair to assume that the collapse of the Soviet Union led to an almost complete transformation of the once-socialist societies, and during this process, the old practices in media and science were fully replaced, i.e. made obsolete. This popular view implicitly extends the inherent antagonism of the Western and Soviet systems to all fields of society, and uses these differences to explain the eventual Cold War outcome. Mihelj [2014] argues that in media research, such binary thinking leads us to ignore possible similarities, universal trends and characteristics that can contribute to a better understanding of the field we study. Her observations, made about television, are also relevant for science 
communication. For example, some similar trends on both sides of the Iron Curtain have been observed by Bauer et al. [2006] and Andrews [2013].

Another rarely asked question is the contribution of Soviet-era practices to the present day science communication in the post-socialist countries. The relevance of the question about the legacy of the Soviet science communication is exemplified by some personal experiences at journalism conferences in Estonia and elsewhere. Now and again, some older scientist or journalist stands up and describes the Soviet media as very science-friendly, contrasting this to the current absent, negligent or 'tabloid' coverage of science and technology. These instances, however anecdotal, contrast the dominant thinking of Soviet science media as pure propaganda and inspire us to dig somewhat deeper into the era.

Science, indeed, had a prominent position in the Soviet society. According to the official rhetoric, "[t]he construction of a new [communist] society [was] unfeasible without the immediate involvement of science in the process" [Köörna, 1986, p. 5]. Some authors saw the Soviet Union and other socialist countries even as a sort of New Atlantis, a scientifically run utopia devised by Sir Francis Bacon:

But the most complete realization of [Bacon's] aims, so far, is to be found in the new socialist states, where social life has been reorganized on scientific lines, and science is pursued according to a comprehensive plan, for the endowment of human life 'with new discoveries and powers'. [Crowther, 1960, p. 4]

The Soviet leadership also saw science and technology as an instrument to demonstrate the superiority of the Soviet socio-economic organization and essential "means for enabling the Soviet Union to achieve supremacy on a global scale and gain its ultimate objective, i.e. the destruction of capitalism" [Harvey, Goure and Prokofieff, 1972, p. 2]. Such instrumentalization of science also led to specific restrictions that determined how science was done. According to Medvedev [1979, p. 118], "the very system of political control over [the] exchange [of information], together with the censorship and the delays in receiving even scientific information that is openly available in foreign academic and scholarly journals, put Soviet scientists in a rather difficult position."

The pressure on scientists to adapt to the demands of the official philosophy of dialectical materialism eased after the death of Stalin, and work on fundamental sciences became more accepted [Ivanov, 2002]. However, applied sciences remained under the political influence and demands for quicker adoption of scientific results to production were constant. In 1971 the continuing dissatisfaction with the progress of the implementation of scientific results led to the introduction of new party control over all scientific research [Harvey, Goure and Prokofieff, 1972].

Similarly, media was under party control and designed to serve, to quote V.I. Lenin, "as an instrument of socialist construction" [Lauristin and Vihalemm, 1993, p. 178]. The media had to be the vehicle for setting standards, telling readers and listeners how to think, behave and act. The media did not have to provide news, i.e. tell about things that have happened, but to "confirm daily that everything was fine and that development was continuing as planned" (ibid., p. 182). Officially, there was no censorship, and the constitution guaranteed the freedoms of speech and the 
press, but in reality, the manuscripts were censored by the editors-in-chief and by the head of the 'party-life' section (as the people most directly responsible for ensuring the ideologically correct line of the newspaper); state censors controlled the proofs and first printed copies [Lauk, 1999].

The level of political control and ideological canonization varied depending on the type of publication. Vihalemm and Lauristin [1997] distinguish a five-level hierarchy. The top category was comprised of the all-Union press and Russian-language newspapers in the Union republics. The Communist Party newspapers in national languages were in the second group in which the ideological control was implemented more flexibly: certain local variations of interpretations and modulations of canonical texts were permitted. Even some criticism of economy could be expressed in analytical commentaries (ibid.). The remaining categories represented lower level (i.e. more local or specialist) publications and were subject to less control.

A similar categorization can be applied to topics. To the first level of political control and ideological canonization belonged the coverage of ideological, political and historical topics of all-Union importance which could be presented only in one, official version (ibid.). On the second level, there was the coverage of local ideological, political and historical topics and also of the economy. We find science on the fourth level along with sport, fine arts and cultural life. This was on the lowest level of official control and sometimes allowed journalists to explore the limits of the permissible.

This hierarchy offers the assumption that next to the official, strictly ideological science coverage there also existed a less controlled sphere where science was communicated to the public. Some personal recollections have even described science as a refuge for journalists who did not want to write about communist ideology [Egikova, 2009], although the freedom of what you could write about was still limited by the censors. Still, the few studies that have investigated science coverage in the socialist states have focussed on the media channels at the top of the hierarchy and, hence, seen a strong ideological focus of the science coverage.

The most studied socialist country concerning the science coverage in the Cold War era is the German Democratic Republic. Kirpal and Ilsmann [2004] looked at the 1970s episodes of the TV show Neue Fernseh-Urania and concluded that the shows were not educational or entertaining, but rather serving the function of being practically relevant. They, as well as Kohring [1997] and Gruhn [1979] highlight the ideological function - legitimizing the leadership, constructing the 'socialist' man, proving the superiority of socialist systems over capitalism and building a harmonious view of the world - as the central factor determining the nature of science coverage. Schirrmacher [2013] concludes that while the pre-war German traditions of popular science survived for some time after the separation of the country into two, the influence of the political order led to the result of the Soviet-style popular science in the GDR becoming stale and implausible, losing its escapist qualities which had allowed readers a break from propaganda.

Bauer et al. [2006] performed a longitudinal comparative study of the British and Bulgarian science coverage between 1946 and 1995, concluding that the intensity of coverage in both countries experienced identical waves: rising from an after-war 
low to a peak in the first half of the 1960s, then declining for much of the 1970s and starting a new rise in the 1980s. There were also similarities in the coverage of some topics. Nuclear power was widely covered in the 1950s and 60s, soon joined in the headlines by space exploration. Environmental news gained prominence in the 1980s, as did computing technology. Yet Bulgaria did not show the trend of 'medicalization of the science news' that occurred in the West. Despite the similarities, the authors conclude that the general pattern of science coverage in the Bulgarian media is consistent with the conception of the totalitarian Bulgaria: "Press coverage of science depended on the current policies of the ruling Communist Party, and no other social input was tolerated." [Bauer et al., 2006, p. 121]

The state control in the Soviet system was commonly achieved with the centralization of all popularization activities into one organization, which in Soviet Russia was the Znaniye Society (and its counterparts in the Soviet republics). While these societies were a strong platform for science propaganda, Andrews [2013] notes that the Znaniye Society also paid much attention to mass-education and mass-enlightenment by managing museums, publishing popular science books etc. Andrews cautions us not to interpret everything in the attitudes and behaviour of Soviet people in relation to science and technology as the result of state propaganda. According to Andrews, the average people both in the USSR and the U.S.A. had a natural interest and pride in their country's achievements:

In essence, these two varied publics (American and Soviet), that seemed so
disconnected on the surface, shared a common process: both publics collected
scientific/technical memorabilia of the space age, they watched films and stage
productions and marched in parades for their heroes, whether Neil Armstrong or Yuri
Gagarin. This dichotomous, yet also unified process, though it was indeed very
orchestrated from above in a politicized manner in different countries, was also
engaged from below by their respective "masses." [Andrews, 2013, p. 524].

These studies leave no doubt that media coverage of science in the former Soviet bloc was impregnated with ideology, serving media's primary function of "maintaining social order or achieving political goals" [Benson, 2008]. However, these studies also suggest that, at least in some cases, there was more to science in the media than just propaganda. We know that during the same period, largely as the result of the 'Sputnik shock' (i.e. the realization by Western countries of the Soviet technological superiority in space), the Western science communication started to focus on the concept of science literacy [Broks, 2006; Nelkin, 1995]. Today, contributing a critical understanding of science - as a method and as an institution - is considered the core of good science communication, including one of the main tasks of science journalism. Thus, the question arises whether similar trends were present in Soviet science reporting and how effective Soviet media was in science communication, since we know that their reporting style, dubbed the TASS style (named after the main Soviet news agency), was not very engaging.

This paper will investigate the Soviet-era science coverage in two Estonian publications: the newspaper Rahva Häal (People's Voice), the official voice of the Communist Party in Estonia, and the magazine Horisont (Horizon), a specialized popular science magazine. Based on the periods of the most and the least intensive coverage of science as identified by Bauer et al. [2006], two time periods were selected from both publications: one from the high-tide and optimistic 1960s, and 
the other from the more critical 1980s when coverage was at its lowest point. The study aims to characterize the coverage following the research questions: what science communication functions beside propaganda (if any) can be identified from the coverage? What differences in coverage (topics, sources, style) can be seen between the two publications and time periods?

This is an exploratory study to characterize Soviet Estonian science reporting. As noted by Stebbins [2008], the exploratory approach is useful when "a group, process, activity, or situation has received little or no systematic empirical scrutiny [or] has been largely examined using prediction and control rather than flexibility and open-mindedness". The wish to go beyond the previous focus on the ideological nature of Soviet science reporting justifies the exploratory nature of this study, attempting to gain understanding of alternative functions of science reporting and to pave the way for an inductive generation of new concepts and empirical generalizations about science media in totalitarian systems.

Descriptive statistics will be used to give some general characteristics of science in the media, followed by an interpretative procedure on the texts to provide deeper insights into how science was presented.

The chosen newspaper Rahva Hääl was the biggest Estonian-language newspaper throughout the Soviet era, and as the official voice of the Communist Party in Estonia, it was also ideologically the most controlled one. Its format remained unchanged over time - a broadsheet newspaper with four pages published every day from Tuesday to Sunday. The monthly magazine Horisont was established in 1967 by the local branch of the Znaniye Society and is still published today.

The analysed articles come from the 1960 and 1980 issues of Rahva Häal and the 1967 and 1980 issues of Horisont. The difference in the year of the publications in the 1960s comes from the fact that data about Rahva Hääl was gathered earlier as part of another project. As Horisont was first published in 1967, it was not possible to create a matching dataset and the earliest possible Horisont data was used instead. However, both years can be considered to represent a period characterized by similar science coverage. Despite the intermediate years experienced the change of political leadership in the Soviet Union, dramatic changes in the society did not start before 1968, and the foundation of Horisont has been considered as part of the science enthusiasm of the 1960s and an aftermath of the Khrushchev thaw [Strandberg, 2011].

For the analysis of Rahva Häal, 8 randomly constructed weeks (a total of 48 issues) were created from both years. Forty-eight random numbers between 1 and 51 (the number of full weeks on both years) were generated in Excel. These represented the weeks of the year for which a weekday was then designated: first 8 of the randomly generated numbers were paired with Tuesdays, the next 8 with Wednesdays, etc. The same set of random numbers was used for both years. If on the assigned day the newspaper was not published, it was not replaced with any other issue but just omitted from the data. For the analysis of Horisont, a constructed issue was created by choosing every $12^{\text {th }}$ article from the bibliography published in the year-end issue of the magazine, starting from the n-th article ( $n$ being a random number between 1 and 12 generated in Excel). In the bibliography, 
all the articles were arranged thematically and, within these, alphabetically after the last name of the author.

For the generation of the descriptive statistics, the study used the principles of the classical approach of quantitative content analysis [Krippendorff, 1980]. The unit of analysis was one newspaper item (article or collection of articles under one headline or an article with an accompanying image). In this study, 'science article' was interpreted as an article that made reference to scientific activities or knowledge, had prominent references to scientific institutions or scientific actors (for example, articles like "Scientists join the Party", December 21, 1960, or "The impressions of Swedish scientists about the USSR", June 3, 1960), or dealt with other institutional processes involving or influencing science (for example, "To the participants of the first session of the Baltic Sea environmental protection commission" by A. Kossygin, the chairman of the USSR Council of Ministers, May $6,1980)$. These inclusions may not directly discuss scientific knowledge but are making enough references to science to be still likely to be interpreted by the readers as part of the discourse of science.

The coding categories used for the articles in Rahva Häal were the length of the article (expressed in relation to the page size), the scientific discipline (divided into four main categories: social sciences and humanities, physical sciences, biomedical sciences, and applied sciences and technology), the motivation for publication (as interpreted from the text - what led to the writing and publication of the article), the information about the author (position and location, as identified from the text) and the location of the event.

For qualitative content analysis, the articles in both Rahva Hääl and Horisont were subjected to close reading during which attention was paid to whether and how the scientific activity was described, in what context science was presented and how the texts were composed. The analysis followed the principles of the interpretive form of qualitative analysis [Gunter, 2000; Wester, Pleijter and Renckstorf, 2004] aimed at the discovery and formation of concepts most relevant for the study. The analysis was conducted in steps: reading all the articles, describing and summarizing the main characteristics of the articles in terms of science reporting (e.g. position of science in the article, presentation style, important actors), formulating interpretive frameworks based on these characteristics (e.g. ideological framing of science, presenting scientists as humans, explaining concepts or problems), and identifying typical and distinctive articles from the sample, based on these frameworks. almost exclusively with Soviet science, the most covered topic was space flights and most articles were short and uninformative.

The 92 analysed newspaper issues (47 from 1960 and 45 from 1980) had in total 206 articles that were coded as science-related articles. The average number per issue was not significantly different between the studied years (2.3 vs 2.1). Almost half $(47 \%)$ of all the items were very short, meaning no more than two or three paragraphs. Another $45 \%$ occupied up to a quarter of a page but usually no more than one column worth of news space. 
The articles deal almost exclusively with the Soviet Union; even other socialist countries are rarely mentioned. While local (i.e. Soviet Estonian) stories are in 1960 on a par with the coverage from the rest of the Soviet Union, by 1980 articles from the rest of the Soviet Union are twice as common as articles from Soviet Estonia, reflecting the political trend of centralization. This is also evident in the statistics of authors. In 1980, there are almost three times fewer Estonian authors than in 1960. Press agencies, i.e. official news sources have become much more prominent, with TASS alone comprising almost half of all by-lined items. In 1960, it comprised a third. Another clearly emerging trend when we compare 1960 and 1980 is institutionalization - there is a significant rise (from 5 articles to 27) in party statements and articles about anniversaries and awards.

Technology and applied sciences is the most covered area, comprising almost half of all articles that could be defined by the area of science. This is largely due to the large number of space articles ( $29 \%$ of all articles). It is followed by biomedical sciences. Physical sciences constitute mere $10 \%$ of the articles, most of them being about earth sciences (e.g. geology, physical geography), with very little physics.

Looking at what initiated the articles, we see a fundamental difference with the modern science reporting. Whereas nowadays reports or peer-reviewed articles are a major news source, the Soviet media rarely (3\%) based their articles on publications. New discoveries and other innovations can be described as the motivation in $12 \%$ of the stories; another $6 \%$ were dealing with research in progress. The most popular reason for publication was what can vaguely be summarized as a science community event or statement (e.g. the launch of a space rocket). In $9 \%$ of the articles it was not possible to determine, based on the modern theory of news values, why the article was published.

\section{Space coverage}

The 1960s' peak in the post-war science coverage can largely be attributed to the achievements on the space frontier. During the first stage of the race, the Soviet Union was the leading force, launching the first satellite in 1957 and sending the first man in space in 1961. The articles related to space flights also form a large and distinct group within all science-related items in this study. They are also the most visible items, with $74 \%$ of them published on the front page.

In 1960, the coverage of the Soviet space program led to two conspicuous peaks in the data: 11 articles on May 17 (the flight of Sputnik 4) and 12 items on August 23, plus another 6 the next day (the flight of Sputnik 5, carrying and returning two dogs, Belka and Strelka). In 1980, no single event had such a massive coverage although new space missions still featured on the front pages. By 1980, the nature of the space program had changed. The era of grand achievements was over, and the Soviet Union was now focusing on its orbital station Saljut. The country took its pride in 'international co-operation', i.e. flying cosmonauts from other socialist countries to space. Although the number of space-related articles in 1980 is equal to 1960, the main bulk of the 1980 articles are dry news items reporting on the launch of another rocket or crew. At the same time, space flights were still framed as scientific missions. 
The front page of the issue of Rahva Hääl, August 23, 1960 is a good example of how space achievements were tied to the general scheme of the Soviet propaganda. Except for a tiny item at the bottom of the page (about the anniversary of the 'liberation' of Romania), the whole page is dedicated to the achievement under the banner "The triumph of the science, technology and industry of our homeland". Besides the Party Central Committee statement and TASS reports about the flight, there is a feature article about the dogs, and the rest of the page is filled with commentaries from various people, both from the scientific community and outside of it - there are factory workers, party officials, pilots, pensioners, a writer and an architect. Sixteen people are commenting on the achievement, and additionally, there is a summary of the press coverage from nine countries on page three. This constructs a multitude of voices all using laudatory adjectives to celebrate the achievement and to praise the socialist system - in essence, adjusting and amplifying the standard ideological messages.

Two items stand out from the coverage for their style and scientific content. The scientific aims of the mission are described in the TASS's piece "Teaduslike uurimiste programm on edukalt täidetud" ("The scientific research program has been successfully completed"). It reads like the methods section of a scientific paper, listing meticulously in plain language the organisms and instruments on board and describing the data transmission and landing procedures. It offers some insights into the technical procedures involved in the mission but no further information about the experiments or their (expected) results. A passive form is used throughout to describe scientific procedures.

The feature article "Nad viibisid kosmoses..." ("They were in space..."), also by TASS, is written in a more narrative style, starting as a reportage from the lab where the returned dogs are studied and turns towards the end into a rather loosely structured question-and-answer interview with an anonymous scientist. The article touches upon the scientific aims of the mission but does not elaborate on the exact experiments or their aims and then focusses on aspects related to the dogs (what breed they are, what they eat etc.). Except for some empty laudatory quotes in the first half of the article, the text provides the reader with the aspects of general interest of the event and thus differs substantially from the rest of the coverage.

In the sample of articles, science itself is only at some level discussed in the front page coverage of the previous Sputnik-flight in May. Again, the TASS report describes the scientific equipment and technical parameters of the flight. Next to it, there are some short comments from Estonian scientists. These discuss the technical and scientific challenges still to be overcome to achieve manned spaceflight such as slowing the ship for re-entry, handling weightlessness and having escape systems for cases of emergency. The comments explain in a simple language why and how these challenges need to be studied and can thus be considered to represent an example of classical popular science writing.

In space coverage, these remained the only examples of articles focussed on explaining scientific issues. We meet the word 'science' frequently also in the space-related articles in 1980 but only as a label to emphasize that all Soviet space activities are only for scientific, i.e. peaceful purposes. A typical example, the article with the title "Taas teadusesadamasse" ("Back to the Haven of Science") discusses no science and only provides a superficial list of research categories. 
The majority of science-related articles (or any articles, for that matter) in Rahva Hääl are not interesting to read. Many items represent the typical Soviet news format: the texts consist of slogans or uninformative statements, and the style is not fluent. They also mostly deal with science as an institution and less with research activities. However, a small number of articles are written on such topics and in such a style that they can be considered to be close to science communication in the modern sense.

The sample included about 20 articles from both years that, on close reading, made an effort to explain science to the reader, either by explaining a scientific concept, the scientific context of the study or problem or the nature of the discovery/advancement. Mostly, these sections were brief, but it still means that, on average, every second issue of Rahva Hääl included one such article. However, in 1960 we can hardly talk about science articles where scientific explanation is the primary aim. We find explanations in articles about scientists and scientific or technological achievements with the primary focus to show that people are committed to work for the improvement of the society and to "confirm daily that everything was fine and that development was continuing as planned" [Lauristin and Vihalemm, 1993, p. 182]. For example, a common genre in the 1960 sample was a photo showing scientists or engineers in their working environment. The by-line sometimes gave a short explanation of the work in progress but sometimes just stated that these-and-these people are doing "scientific studies". Also, in many other articles we see the tendency to report on the "what?" but not "why?" or "how?".

Three articles from 1960 deserve a closer look as exceptions to the general style of reporting. The article of July 7 "Inimese mõistusega, masina kiirusega" ("With the Intellect of the Human, with the Speed of a Machine") is an introduction to the science of cybernetics, adopted from Russian-language newspapers. The article provides an overview of the origins and aims of cybernetics and gives examples about the use of computers in businesses. The first half of the article is in a neutral and popularizing tone. The second half deals with the impact and adopts a clearly ideological position - automatization of factories in the Soviet Union benefits the people and the economy, but in the US it only contributes to unemployment (and is therefore misused). Still, the article stands out for the length devoted to explaining science and for the placement of the scientific ideas before the ideological explanations.

The article of September 27 "Vulkaani tipult ja geisrite orust" ("From the Top of a Volcano and from the Valley of Geysers") reports on a trip of Estonian scientists to the Far East part of Russia. No scientific studies are described; rather the journalist asks them to describe the journey and share their impressions. The result is an entertaining general interest article, devoid of slogans or ideological framing and showing the human side of scientists.

The third article "Eksperimentaallaboratooriumis" ("In an Experimental Lab" by E. Varul) from August 12 combines scientific explanation and the journalistic feature style. The article provides a well-structured narrative about ongoing research. It starts with a reportage: 
"Closure... To the right... Further..."

Concise orders. Clanks of instruments. It smells strongly of ether.

The concentrated faces of surgeons sometimes display increasing pressure. This

happens at the moments when all comes down to one small move. But the 'patient'

breaths evenly, deeply and calmly... [translations here and later by the author]

The article continues to explain that the operation is conducted on a dog, practicing the transplantation of blood vessels. This procedure allows saving people whose vessels have become blocked and would otherwise need amputation, as the doctor explains:

\begin{abstract}
"Now imagine that we transplant here," his finger points to the knee area, "a piece of new artery, we place a new segment on the congested place. The leg is nourished again and the patient's health will be restored and impairment avoided. This is our goal. But before such operations can be performed on humans we must experiment on animals."
\end{abstract}

The article distinguishes itself from the rest by its fluent and engaging style and the lack of ideological references, proving that eloquent and research-focussed science writing was possible in 1960. At the same time, the text represents the general pattern of reporting research-in-progress (instead of results) and does not ask any critical questions about science.

In 1980, we already see a number of texts that allow us to talk about the science news genre. These articles have their sole focus on science, present research results and have much less official jargon compared with the 1960 coverage. The ideological statements or references, if present, have moved to the rear part of the text and no longer dictate the structure of the article. We see more emphasis on explaining the science and a more frequent use of the feature style. This can be seen both for locally and centrally produced articles (the news agencies ETA and APN, respectively). Here is one rather poetic excerpt from the article "Kivist ilmakroonika" ("Stony weather chronicle" by K. Zahharov, ETA) from the June 13 issue:

The sun set, the ancient farmer took a cobblestone before going to bed and went down on his knees in front of the big stone on the edge of his field. With this simple tool our ancient ancestor made cup-marks in the stone, worshipping the great and eternal creator - Sun - and marking another sunny day, so rare here in the Baltics. According to the scientists' assumptions, this is how the hollows were created on the cult stones of which more than a thousand are found in Estonia.

Cult stones have a different number of cup-marks but most have 10 and more. One such mark with a smooth edge and certain depth could be created with just 3-5 blows. By multiplying the number of cup-marks with this number the scientists got the average number of sunny days during the fieldworks period. This discovery confirmed the archaeologists' hypothesis: cult stones are a kind of stony weather chronicles directly connected with the ancient worshipping of sun and rain.

The article, however, does not mention any sources by name or institution. This reflects the trend of the increasing entertainment value of the science items, also exemplified by the appearance of small science-related items in the easy-reading section "Varia" ("Miscellaneous"). One item from the sample simply retold funny 
anecdotes from science history. However, other science news explained achievements awarded the Lenin Prize (one of most prestigious awards in the Soviet Union) or other recent developments (for example, new modes of transport such as the electric car and the hydrogen car). The dominant discourse is still the popularization of science, and no critical questions were asked.

\section{Popular science magazine Horisont}

Since its launch in 1967 Horisont has been one of the cornerstones of science communication in Estonia. Over the years, it has engaged numerous scientists as co-authors and is often referred to by today's scientists as the publication that inspired them to choose a career in science.

Based on the bibliographies published in the year-end issue of the magazine, Horisont published 232 articles in 1967 and 196 articles in 1980. In 1967, the most popular topics were 'astronomy, physics and mathematics' and 'biology and medicine', both with 34 articles, followed by 'history, archaeology and ethnography' with 24 articles. In 1980, 'history, archaeology and ethnography' had become the most popular topic (22 articles), closely followed by 'various' (21) and 'physics, chemistry and astronomy' (20). Medicine and biology were now treated as separate topics but, when combined, would have topped the 1980 list $(12+15)$. The 1967 issues featured a much higher proportion of articles related to hobbies and DIY (stamp collecting, model building, photography, fishing). New topics in 1980, compared to 1967, included several fields of social sciences (economy, education, demographics) but also cybernetics and environmental protection. In 1980, the magazine no longer published fiction. The 1967 sample for this study included 19 articles, the 1980 sample 16 articles.

The 1960s articles in Horisont and Rahva Häal are distinctly different in their style, the selection and presentation of scientific topics. The analysed 1967 texts from Horisont are predominantly free of the socialist ideology, are much more likely to use journalistic and narrative style, and deal with many of the up-to-date topics of the day. While in Rahva Hääl, science was mainly instrumentalized for ideological purposes and making abstract promises of a better future, the focus of Horisont's articles is scientific activity itself, showing specific benefits and discussing the difficulties. Science is mainly presented as 'puzzle solver': a typical longer article in Horisont begins with a description of an unsolved problem or questions that have puzzled scientists or may puzzle the reader (e.g. the first sentence of an article about radioactive isotope measurement from December issue: "How old are the Earth, the planets, the Sun? This has interested mankind for centuries"). Then such articles move on to describe efforts of scientists to understand the problem, including detailing used methods. The articles usually give an overview of the historic development of the field, describe the solving of some of the puzzles, but often conclude with a number of questions still unanswered and which scientists are still working on. Examples of topics covered in such articles include tectonic phenomena, impact of microbiome to organisms, in vitro cultivation of tissues, and a novel power production plant.

Whereas Rahva Hääl used value statements and other labelling devices (such as 'capitalist') to demarcate the Soviet and the Western, such devices are generally 
absent in Horisont, indicating that the magazine embraces the universal nature of science. The majority of analysed articles do not place specific emphasis on Soviet science when discussing a certain field of science. The official style and ideological biases are not completely absent, however. The articles about revolutionaries depicted on stamps and principles of Nobel prizes employ typical Soviet jargon, the article about a novel power plant introduces a debate between some 'bourgeois philosophers' and Soviet scientists about the benefits of space exploration, and the article about semiconductors leaves the impression that the Soviet scientists were already working on the transistor before World War II and does not mention the name or place of the actual invention of the device. But altogether the use of such devices is much less prominent and obtrusive than in Rahva Hääl.

An interesting example is an article called "Teed teadusse" ("Roads to science", March 1967). The article focuses on the life of a women historian, describing the hardships experienced by her before managing to establish a scientific career. The article's ideological undertone is clear - the previous 'bourgeois' era (i.e. first period of Estonia's independence 1918-1940) did not favour women to pursue higher education and specialist positions in the society, whereas Soviet regime has brought equality. The devices used to convey this message are, however, much less explicit when compared to the usual style of Soviet journalism. The article makes no direct statements contrasting the regimes but opts for the stylistic device of comparison. The career path of the historian is described as bumpy due to societal circumstances, and it is placed next to the smooth career of another female scientist who started in the Soviet era and has experienced no material or societal restrictions. The statistics about the Soviet workforce, emphasizing the equality and high education levels are presented in separate factboxes. Due to the narrative style and the avoidance of the explicit ideological messages, the article can be read simply as a story of two women. This indicates that the magazine found ways in which to present obligatory ideological materials in ways which also have other qualities for the readers.

The use of narrative style is characteristic to many articles of the 1967 sample, making the magazine interesting and educational to read even today, 50 years later. In comparison, the 1980 sample of Horisont is less likely to use narrative elements, preferring simple explanatory or descriptive style. One of the few places where the narrative approach is still visible in 1980, are articles adopted from Western magazines (such a National Geographic or Scientific American; the practice of adopting Western articles is present on both surveyed years). Such articles are also the few pages in the magazine that present latest scientific advances and discoveries. The turn away from scientific frontiers is one of the significant observable changes between the two surveyed years (despite the editor-in-chief being the same person). The articles describing latest advancements in a certain field have been replaced by more timeless overviews (such as the nature of sleep, history of libraries, coin discoveries in Estonia) or introduction of more specific results, in our sample the sociological survey of Estonian students and the latest archaeological excavations in Tartu. This exemplifies also the other prominent shift - that from presenting world science to Soviet and Estonian science. This is most clearly evident from the selection of short news stories. In 1967, all news items discussed the discoveries by Western researchers; in 1980, however, only Soviet science was presented in the news. 
The content is still able keep itself largely free of ideological slogans although the number of articles where institutional or perceived ideological focus takes prevalence over scientific content is higher in the 1980 sample. For example, the article about the orbital station Saljut 6 (April 1980) remains a dry description how the station operates, only the image captions introduce the latest experiments conducted at the station; another article "Iga kolmas ajaleht, iga kümnes tonn soolamaaki" ("Every Third Newspaper, Every Tenth Ton of Salt Ore", December 1980) is a description of the heavy industry of the Ural area and its importance to Soviet economy. Despite the use of elements of reportage in that article, it does not become an appealing read on its own.

Previous studies looking at Cold War era science coverage in the media of socialist countries have focussed their attention on the ideologically-determined aspects of the coverage. Looking at the science coverage in Soviet Estonian publications Rahva Hääl and Horisont in 1960/1967 and 1980, this study also found that most of the science-related articles in Rahva Hääl served ideological purposes and did not explain the science. The use of science to legitimize the socialist system was especially strong in 1960. The number of articles that were dedicated to popularization of science, i.e. were well-written science news or features and explained science, was small in both years, although had increased in 1980 when science news was also used for entertainment value.

Rahva Häal's comparison with Horisont supports the notion that rigidity of ideological control varied depending on the topic and outlet. As a specially dedicated popular science magazine, Horisont mostly avoided the coupling of science and socialist ideology. Especially in 1967, it featured articles about recent advances in world science without attaching any value claims to Western achievements. Also, Horisont's articles were written in an eloquent and narrative style rarely seen in Rahva Hääl.

By 1980, both outlets had come closer to each other, both in terms of style and the selection of topics. They both now carried more articles about Estonian and Soviet science compared to international science. While Rahva Hääl now had more news reporting about latest advances, Horisont had shifted away from the scientific frontiers. While these results partly confirm the changes in media coverage of science as noted by Bauer et al. [2006] and Schirrmacher [2013] and can be explained by general stagnation of the society, the difference between 1960s and 1980 in this study is not huge.

This study reveals the diversity of science coverage in the Soviet media. Where many others have previously seen only ideology-driven coverage, a closer look shows us authors and publications that within these restrictions produced articles about science that could also be published today, when the media and science operate on radically different rules. This suggests that the question of similarities between the Soviet and Western science communication is worth further study as it might help to understand some of the universal features of communicating science.

Science communication is a fairly recent concept. During the period under our investigation the prevalent term was 'popularization', i.e. simplifying the science to the wider audience. In his paradigm-shifting paper Hilgartner [1990] showed how 
this term keeps knowledge to the exclusive realm of scientists and hence this approach is not able to deal with the aims scientists and the society had set for communication of science. Since then, major emphasis has been put on engagement and dialogue. The role of the media is to become a democratic platform for discussions and also contribute to scientific literacy, i.e. critical understanding of science's way of operating.

Can we and should we look at Cold War period science communication from that perspective? That could bring new insights, both by showing how some concepts were completely irrelevant in that context and how some concepts were operational even before they were academically identified and consciously applied. It can also help us to analyse science communication in the journalistic systems that still operate under censorship regime, such a China.

This study found little indication that science communication in Soviet print media had progressed further than popularization. This is evident by the lack of critical approach and deeper insights into the nature of science, although Horisont presented some scientific discussions and methods, thus contributing to increasing the scientific literacy of the readers. However, to understand why the status of science communication in Soviet media is important we must again remind ourselves that the function of Soviet media was very different. Its main goal was not to give information but to reinforce discourses. When reporting science, the official function of the article was not related to promoting science or even ensuring 'public appreciation for the benefits that science provides to society' as Lewenstein [1992] describes the Western situation. It was to continuously confirm the Socialist system as superior. However, this study also showed that not all articles matched this scheme and actually became prevalent on the level where ideological control was weaker. Why did we have science articles in Rahva Hääl, although only a few, that were just about science and written in an engaging style? Why did Horisont discuss topics that were far from 'putting science into practice', as the slogan of day demanded? The answer to these questions teaches us something essential about science communication as it tells us that the concept of communicating science existed in the Soviet media, despite embodying a deviation from the norm.

This paper remains an informal exploratory study with a small sample, intending to map the basic features and trends in the Soviet Estonian science coverage. To confirm the observations and explain the reasons behind the changes, a more in-depth quantitative and qualitative analysis would be needed, including content analysis and also interviews with journalists and editors from the era to understand how censorship operated and editorial decisions were made. Also, a better understanding of the operation of science communication in a censorship regime would require further studies in more countries and on more channels. The experience of other countries might be different from that of Estonia, a small and educated country which as part of the Soviet Union still had some ties with the West (through illegal watching of Finnish television). Today, Estonia has successfully integrated with Western institutions, also regarding science communication [Bucchi and Trench, 2014] whereas in other post-Soviet, post-socialist or totalitarian countries the transition might still be in progress or yet to start. 
Methodologically, this paper shows that conclusions about the nature of (science) coverage should be made based not only on the study of the top-level publications that are most tightly ideologically controlled. Lower-lever newspapers and magazines had more journalistic freedom in the Soviet system, providing at times coverage of very different nature.

\section{References}

Andrews, J. T. (2013). 'An Evolving Scientific Public Sphere: State Science Enlightenment, Communicative Discourse, and Public Culture from Imperial Russia to Khrushchev's Soviet Times'. Science in Context 26 (03), pp. 509-526. DOI: $10.1017 / \mathrm{s} 0269889713000161$.

Bauer, M. W., Petkova, K., Boyadjieva, P. and Gornev, G. (2006). 'Long-Term Trends in the Public Representation of Science Across the "Iron Curtain": 1946-1995'. Social Studies of Science 36 (1), pp. 99-131. DOI: 10.1177/0306312705053349.

Benson, R. (2008). 'Journalism: Normative Theories'. In: The international encyclopedia of communication. Ed. by D. Donsback. Wiley-Blackwell.

Broks, P. (2006). Understanding Popular Science. U.K.: McGraw-Hill Education.

Bucchi, M. and Trench, B., eds. (2014). Routledge Handbook of Public Communication of Science and Technology. 2nd ed. London, U.K. and New York, U.S.A.: Routledge. URL: https ://www . routledge . com/Routledge-Handbo ok-of-Public-Communication-of-Science-and-Technology-Second/BucchiTrench/p/book/9780415834612.

Crowther, J. G. (1960). Francis Bacon: the first statesman of science. Cresset Press.

Egikova, V. (2009). 'Russian science journalism: the past and the future'. Ethics in Science and Environmental Politics 9, pp. 29-32. DOI: 10.3354/esep00099.

Gregory, J. and Miller, S. (2000). Science in public. New York, U.S.A.: Basic Books.

Gruhn, W. (1979). Wissenschaft und Technik in deutschen Massenmedien. Ein Vergleich zwischen der Bundesrepublik und der DDR. Erlangen.

Gunter, B. (2000). Media research methods: measuring audiences, reactions and impact. London, U.K.: SAGE Publications.

Harvey, M. L., Goure, L. and Prokofieff, V. (1972). Science and Technology as an Instrument of Soviet Policy. Center for Advanced International Studies, University of Miami.

Hilgartner, S. (1990). 'The Dominant View of Popularization: Conceptual Problems, Political Uses'. Social Studies of Science 20 (3), pp. 519-539. DOI: $10.1177 / 030631290020003006$.

Ivanov, K. (2002). 'Science after Stalin: Forging a New Image of Soviet Science'. Science in Context 15 (02). DOI: 10.1017/s0269889702000467.

Kirpal, A. and Ilsmann, A. (2004). Die DDR als Wissenschaftsland? Themen und Inhalte von Wissenschaftsmagazinen im DDR-Fernsehen. TU Ilmenau, Institut für Medien- und Kommunikationswissenschaft, 13. URL: https://www.db-thue ringen.de/servlets/MCRFileNodeServlet/dbt_derivate_00014236/Diskussi onsbeitrag_13_DDR\%20als\%20Wissenschaftsland_Kirpal.pdf (visited on December 2016).

Kohring, M. (1997). Die Funktion des Wissenschaftsjournalismus: Ein systemtheoretischer Entwurf. Germany: Westdeutscher Verlag.

Köörna, A. (1986). Science Serving the People. Tallinn, Estonia: Perioodika.

Krippendorff, K. (1980). Content Analysis: An Introduction to Its Methodology. Newbury Park, London, New Delhi: Sage Publications.

Lauk, E. (1999). 'Practice of Soviet Censorship in the Press: The Case of Estonia'. Nordicom Information (3), pp. 27-39. 
Lauristin, M. and Vihalemm, P. (1993). 'The Communist Press in the Soviet Republics'. In: Towards a Civic Society: The Baltic Media's Long Road to Freedom. Ed. by S. Hoyer, E. Lauk and P. Vihalemm. Tartu, Estonia: Baltic Association for Media research/Nota Baltica, pp. 177-187.

Lewenstein, B. V. (1992). 'The meaning of 'public understanding of science' in the United States after World War II'. Public Understanding of Science 1 (1), pp. 45-68. DOI: $10.1088 / 0963-6625 / 1 / 1 / 009$.

Medvedev, Z. A. (1979). Soviet Scienc. Oxford, Melbourne: Oxford University Press. Mihelj, S. (2014). 'Understanding Socialist Television: Concepts, Objects, Methods'. Journal of European Television History and Culture 3 (5), pp. 7-16.

Nelkin, D. (1995). Selling Science. How the Press Covers Science and Technology. Revised edition. New York, U.S.A.: Freeman and company.

Oreskes, N. (2014). 'Introduction'. In: Science and Technology in the Global Cold War. Ed. by N. Oreskes and J. Krige. Cambridge, MA, U.S.A.: The MIT Press, pp. 1-10.

Schirrmacher, A. (2013). 'Popular Science as Cultural Dispositif: On the German Way of Science Communication in the Twentieth Century'. Science in Context 26 (03), pp. 473-508. DOI: 10.1017/s026988971300015x.

Stebbins, R. A. (2008). 'Exploratory Research'. In: The SAGE Encyclopedia of Qualitative Research Methods. Ed. by L. M. Given. Thousand Oaks, U.S.A.: SAGE Publications.

Strandberg, M. (12th December 2011). 'Mis on Horisondi taga? [What is Beyond the Horizon?]' Sirp. URL: http://www. sirp.ee/s1-artiklid/c9-sotsiaalia/mison-horisondi-taga/ (visited on April 2017).

Vihalemm, P. and Lauristin, M. (1997). 'Political Control and Ideological Canonisation. The Estonian Press during the Soviet Period'. In: Vom Instrument der Partei zur "Vierten Gewalt". Die ostmitteleuropäische Presse seit 1945 als zeithistorische Quelle. Ed. by E. Mühle. Marburg, Germany: Verlag Herder-Institut, pp. 103-109.

Wester, F., Pleijter, A. and Renckstorf, K. (2004). 'Exploring newspapers' portrayals: A logic for interpretive content analysis'. Communications 29 (4).

DOI: 10.1515/comm.2004.29.4.495.

Arko Olesk is a researcher in Tallinn University currently finishing his Ph.D. about mediatization of scientists. He has a background in science journalism and received his previous degrees from University of Tartu and Imperial College London. E-mail: arko.olesk@tlu.ee.

\section{How to cite}

Olesk, A. (2017). 'Beyond propaganda: science coverage in Soviet Estonian media'. JCOM 16 (03), A06. 